\title{
Determinants of Customer-Based Retailer Equity: An Empirical Verification Approach from Indian Large Retail Market
}

\author{
Ramulu Bhukya \\ School of Management Studies, University of Hyderabad \\ Hyderabad-500046, India \\ Tel: 91-95-0246-5229Ｅ-mail: ramulubhukya@uohyd.ac.in
}

Received: August 17, 2014 Accepted: November 21, 2014 Published: February 1, 2015

doi:10.5296/jmr.v7i2.6949

URL: http://dx.doi.org/10.5296/jmr.v7i2.6949

\begin{abstract}
The aim of this study is to examine and verify the applicability of customer-based brand equity model based on Aaker's well-known brand equity framework from customers' standpoint in the Indian large retailing. It is conceptualized that retailer equity is determined by four dimensions-retailer awareness, retailer associations, and perceived retailer quality and retailer loyalty. Mall intercept method is applied to choose and contact shoppers with the structured questionnaire at the outlets of large Indian retailers. A total of 312 valid and useable questionnaires are obtained, wherein responses are recorded on 5 point Likert-type scale, with 1 being strongly disagree and 5 strongly agree. Then, the analysis was carried out by Confirmatory Factor Analysis (CFA) and Structural Equation Modelling (SEM). Findings of this study reveal that except retailer awareness, all the other three retailer equity dimensions- retailer associations, perceived retailer quality and retailer loyalty have the positive and significant influence on overall retailer equity. Among these, retailer loyalty is found to be the most influential determinant of overall retailer equity. Thus, based up on the results, it was confirmed that Aaker's brand equity model is also applicable to the Indian large retail industry. Hence, retailers should consider relative importance of these dimensions while evaluating their overall equity. This study is of great interest for large retailers who wish to increase their brands' value proposition to the marketplace.
\end{abstract}

Keywords: Retailer equity, Retailer awareness, Retailer associations, Retailer perceived quality, Retailer loyalty, Structural equation modelling, India 


\section{Introduction}

In recent years, with the emergence of private labels concept, retailers are making considerable effort to increase their customer based brand equity by engaging in various brand management activities. For example, retailers offer the market differential value with a view to stimulate customer loyalty and so on. Building retailer equity increases revenue and profitability by insulating retailers from competitors. Moreover, with the assortment of consumer needs and wants, retailers have been forced to create various sustainable competitive tactics. For this, retailers must have a good understanding of brand equity from the consumers' perspective (Taskin and Akat, 2010). Customer based retailer equity plays a strategic role in determining customers' purchase decisions and considered as the most important concept in business and academic research (Kim, Kyung Hoon, et al. 2008) because a positive customer-based retailer equity can help retailers in many ways, for example, it generates greater revenue, lower the sourcing or manufacturing costs, and increases profits and it will enhance the firm's ability to expertise and charge more and premium prices, and ultimately leads to the attainment of brand extensions (Keller, 2003). Hence, understanding the customer based brand equity will help brand managers in gaining competitive advantage over competitor brands and make wise management decisions. The necessity for substantial evidence of consumer-based equity conception has directed to the improvement of an extensive varied brand equity models. Thus, this study is aimed to verify and examine the applicability and practicality of the Aaker's well-known customer based brand equity framework.

\section{Review of Literature}

\subsection{Retailer Awareness}

Brand awareness is the first and foremost important component of brand equity (Aaker, 1991; Keller, 1993), it plays a prominent role in purchase intention as consumers like to buy a product with which they aware of (Keller, 1993; Macdonald, E. K., \& Sharp, B. M., 2000). Keller (1993) points out that brand awareness further comprises two sub-dimensions: one is brand recall and the other is recognition. Brand recognition plays a prominent role in forming brand communication, in turn it helps a firm to communicate attributes related to the product with which to associate them till a brand name is recognized. It will help consumers to identify a brand from its competitors and make decision to purchase (Percy, L., \& Rossiter, J. R. 1992). As the brand holds good amount of brand awareness will certainly have a greater amount of market share and a superior brand image (Grewal, et al., 1998) and it will be the same instance with retailer brand. Hence, it was assumed that a retailer brand with higher brand awareness will create a greater retailer equity. Thus the following hypothesis is developed:

H1: Retailer awareness has positive and significant effect on overall retailer equity.

\subsection{Retailer Associations}

Brand associations are another important component of brand equity (Aaker, 1991; Keller, 1993) and a core part of Consumer Based Brand Equity (Romaniuk and Nenycz-Thiel, 2011). 
Aaker (1991) recommended that brand associations create positive attitudes and feelings among consumers and could provide them value by providing the reasons for why consumers should buy the product or service of the particular brand. Brand associations are a key element in brand equity formation and management (Rio et al., 2001) and high brand equity implies that consumers have strong positive associations with respect to the brand (Atilgan et al., 2005). According to Tong, \& Hawley, (2009), customer-based brand equity takes place only when consumers are well-aware of a brand and carrying the favorable, unique brand associations in their memories. Thus, it was assumed that, strong retailer associations form the higher retailer equity and hence it is posited that;

$\mathrm{H} 2$ : Retailer associations have positive and significant effect on overall retailer equity.

\subsection{Perceived retailer quality}

This is an another important dimension of brand equity (Aaker, 1991) and central aspect of customer based brand equity frameworks (Farquhar, 1989; Keller, 1993; Aaker, 1996; Dyson et al., 1996; Netemeyer et al., 2004). Zeithaml, (1988, p. 3) stated the perceived quality is in fact, not the actual quality of the product, it is the subjective evaluation by consumers for the product. Perceived means that the customers decide upon the level of quality, not the company (Ogenyi Omar, 2009). According to the Burmann et al., (2009), for the establishment of powerful brand, firms should measure the buyer's positive or negative perception of a brand. Knowing how to perceive quality by consumers can provide important advantages for businesses. Thus, it was assumed that, strong perceived retailer quality form the higher retailer equity. Hence the hypothesis is posited that;

H3: Perceived Retailer quality has positive and significant effect on overall retailer equity.

\subsection{Retailer loyalty}

Brand loyalty is the most critical and important dimension of consumer-based brand equity and it directs consumers' intention to purchase the products repeatedly (David, A. Aaker., 1991; Jung, J., \& Sung, E., 2008). Brand loyalty is further consist of two sub-dimensions: one is affective loyalty and the other one is action loyalty. Affective loyalty is formed out of an accumulative satisfaction gained from previous usage experiences. But, it just represents that the future purchase intention. Aaker (1991) emphasizes that brand loyalty complements substantial value to a brand/firm and thus it helps in attracting and retaining the repeated and as well new buyers in longer duration. Thus, it was assumed that, strong retailer loyalty form the higher retailer equity. Hence, the hypothesis is posited that;

H4: Retailer loyalty has positive and significant effect on retailer overall brand equity.

\section{Methodology}

To test the above conceptualized research hypotheses, a research framework was designed and conducted an empirical study on shoppers of large retailers in India. Mall intercept method was employed to select the shoppers and collect their perceptions on conceptualized retailer equity dimensions, which were developed from Aaker's consumer based brand equity framework. To collect the primary data, a research questionnaire was designed by including 
measurement items of consumer based brand equity scale (see the table 1) comprising of four exogenous constructs (retailer awareness, retailer, perceived retailer quality and retailer loyalty and an endogenous construct (overall retailer equity), which were adopted from previous literature and extended to retail industry. Responses were recorded on 15 -point Likert scale where $1=$ strongly disagree and $5=$ strongly agree. Total of 450 shoppers were requested to participate in the survey but only 312 agreed and filled the questionnaires. It shows 69 percent of response rate. According to Hair et al., (2010), a sample size of 200 or more is enough for developing structural equation models and thus it is fulfilled in the study. Then, the analysis was carried out by employing structural equation modelling statistical technique on AMOS 21v. Anderson's (1988) two-step approach is applied. In the first step, measurement model is analyzed in order to ensure constructs' adequate reliability and validity by using confirmatory factor analysis. In the second step, the proposed hypotheses related to the constructs are tested by using structural equation modeling. This study followed the model fit criteria recommended by Hair et al., (2010).

\section{Results}

\subsection{Demographic characteristics of the respondents}

As the study was conducted on total 312 respondents, male and female respondents forms 62 percent $(n=193)$ and 38 percent $(n=119)$ respectively. Majority (78 percent) of the respondents' income level was above $₹ 20000.45$ percent $(n=140)$ possess graduation degree, 74 percent $(n=230)$ are in age group of $21-45$ year, 36 percent $(n=112)$ were the regular buyers. Thus the present study has the well composition of samples' demographical characteristics.

\subsection{Reliability and validity analyses of measures}

In order to examine the internal consistency of the items, reliability of the scale used in the study was tested by using Cronbach's' alpha method for each dimension and overall together. Items with Cronbach's 'coefficients greater than 0.7 were only retained in the study. Cronbach's' coefficients of all the five constructs were found between the range of 0.82 to 0.921 after deleting 2 items. Finally 16 items were included and retained for the analysis.

\subsection{Results of measurement model}

Confirmatory factor analysis (CFA) was performed for the five constructs in order to examine the convergent and discriminant validity of respective constructs by employing AMOS $21 \mathrm{v}$. The values the model fit indices found within the acceptance limits suggested by $\mathrm{Hu}, \mathrm{L}$. T., \& Bentler, P. M.,( 1999); Knile, (2005); Lia et al., (2007); Hair et al., (2010) ; Awwad and Agti ,(2011). The values of absolute fit measures indices of measurement model were found in the acceptable limit. Where, Chi-Square $=286.95$ and significant at 138 Degrees of freedom. Thus $\chi 2 / \mathrm{df}=2.079$, Goodness of Fit Index $(\mathrm{GFI})=.941$ and Root Mean Square Error of Approx. (RMSEA) $=.048$. Similarly, the values of incremental fit measures were also found in the limit of acceptance. Where, Adjusted Goodness of Fit Index (AGFI) =.916, Normed Fit Index (NFI) =.951, Incremental Fit Index (IFI) =.959, Tucker-Lewis Index (TLI) $=.961$ and Comparative Fit Index $(\mathrm{CFI})=.963$. Loadings of all the factors were significant 


\section{Macrothink}

Journal of Management Research

ISSN 1941-899X

2015, Vol. 7, No. 2

and in the range between 0.70 and 0.93 , which were considered as good loadings and were shown in the table-1.

Table 1. Result of Confirmatory factor analysis

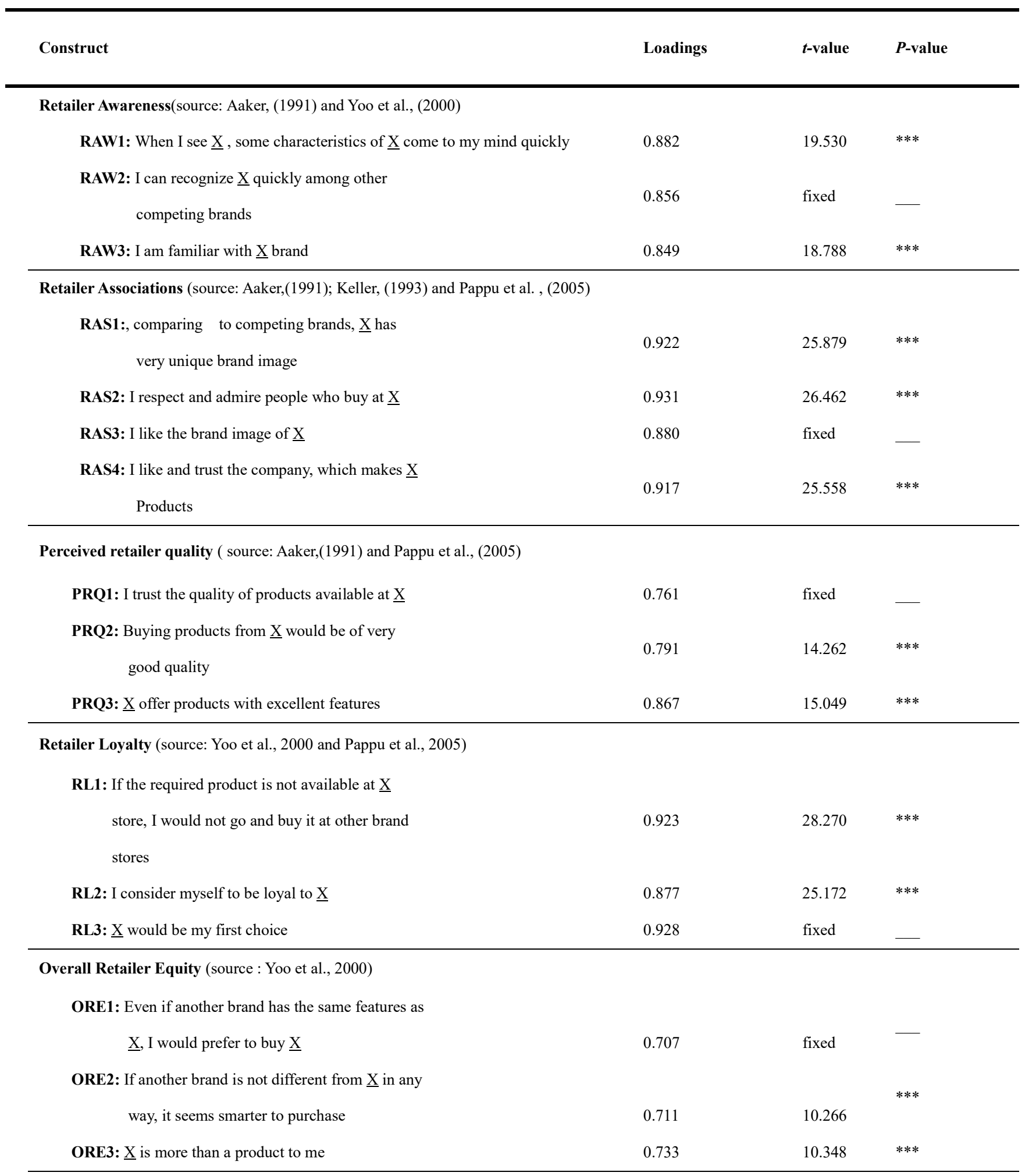

Notes: $\underline{\mathbf{X}}$ represnts the specific brand; - represents the path parameter was fixed to 1, therefore, t-value were not presented. 


\subsubsection{Convergent and discriminant validity}

Convergent validity tests the internal consistency of items within a construct. I other words, there should be strong correlation between items and corresponding construct and weak with the others. It was assessed by composite reliability (CR) and the average variance extracted (AVE). A convergent validity is said to be established when it follows two criteria. Firstly, the composite reliability of each factor should be greater than the average variance extracted by that factor (CR > AVE); secondly, the value of composite reliability of each factor should be more than 0.70 and the average variance extracted by that factor should be more than 0.50 (AVE > 0.50). The composite reliability of all the five constructs were between 0.77 and 0.898 and the AVE of each constructs were between 0.51 and 0.671 which were above the acceptable limit (see the table-2a). Hence, all the five constructs followed convergent validity.

Table 2a. Convergent validity analysis of the constructs

\begin{tabular}{l|llll}
\hline \multicolumn{7}{c}{ Convergent validity } & & & \\
\hline & CR & AVE & MSV & ASV \\
\hline Retailer awareness & 0.868 & 0.647 & 0.171 & 0.088 \\
Retailer association & 0.898 & 0.671 & 0.151 & 0.094 \\
Retailer Loyalty & 0.802 & 0.560 & 0.128 & 0.072 \\
Perceived Retailer quality & 0.774 & 0.501 & 0.171 & 0.150 \\
\hline
\end{tabular}

Similarly, the discriminant validity of the scale can be evaluated by two methods, either inter-construct correlation matrix or based up on variance extracted method. In the first method, there should be weak correlation with other constructs and highest correlation with the same construct. This criteria was met for this study (see table 2b). On the other hand, Maximum Shared Squared Variance (MSV) of each construct should be lesser than Average Variance Extracted (AVE) of corresponding construct and similarly, Average Shared Squared Variance (ASV) should be lesser than Average Variance Extracted (AVE). This criteria was also met in this study (see table $2 a$ ).

Table $2 \mathrm{~b}$. Discriminant validity analysis of the constructs

\begin{tabular}{l|llll}
\hline & \multicolumn{4}{|c}{ Discriminant validity } \\
\hline & $\begin{array}{l}\text { Retailer } \\
\text { awareness }\end{array}$ & Retailer association & $\begin{array}{l}\text { Retailer } \\
\text { Loyalty }\end{array}$ & Perceived \\
& retailer quality \\
\hline Retailer awareness & $\mathbf{0 . 8 0 4}$ & & & \\
Retailer association & 0.262 & $\mathbf{0 . 8 1 9}$ & $\mathbf{0 . 7 4 8}$ & \\
Retailer Loyalty & 0.160 & 0.251 & 0.358 & $\mathbf{0 . 7 0 8}$ \\
Perceived Retailer quality & 0.413 & 0.389 & & \\
\hline
\end{tabular}




\section{$\triangle$ Macrothink}

\subsection{Structural Equation Modeling}

After obtaining convergent and discriminant validity besides achieving good model fit indices of measurement model, then moved further to test the hypothesized relationships of conceptual model by employing structural equation modelling (see the Figure 1). It was observed that all the four dimensions constitute for 59 percent of total variance in overall retailer equity.

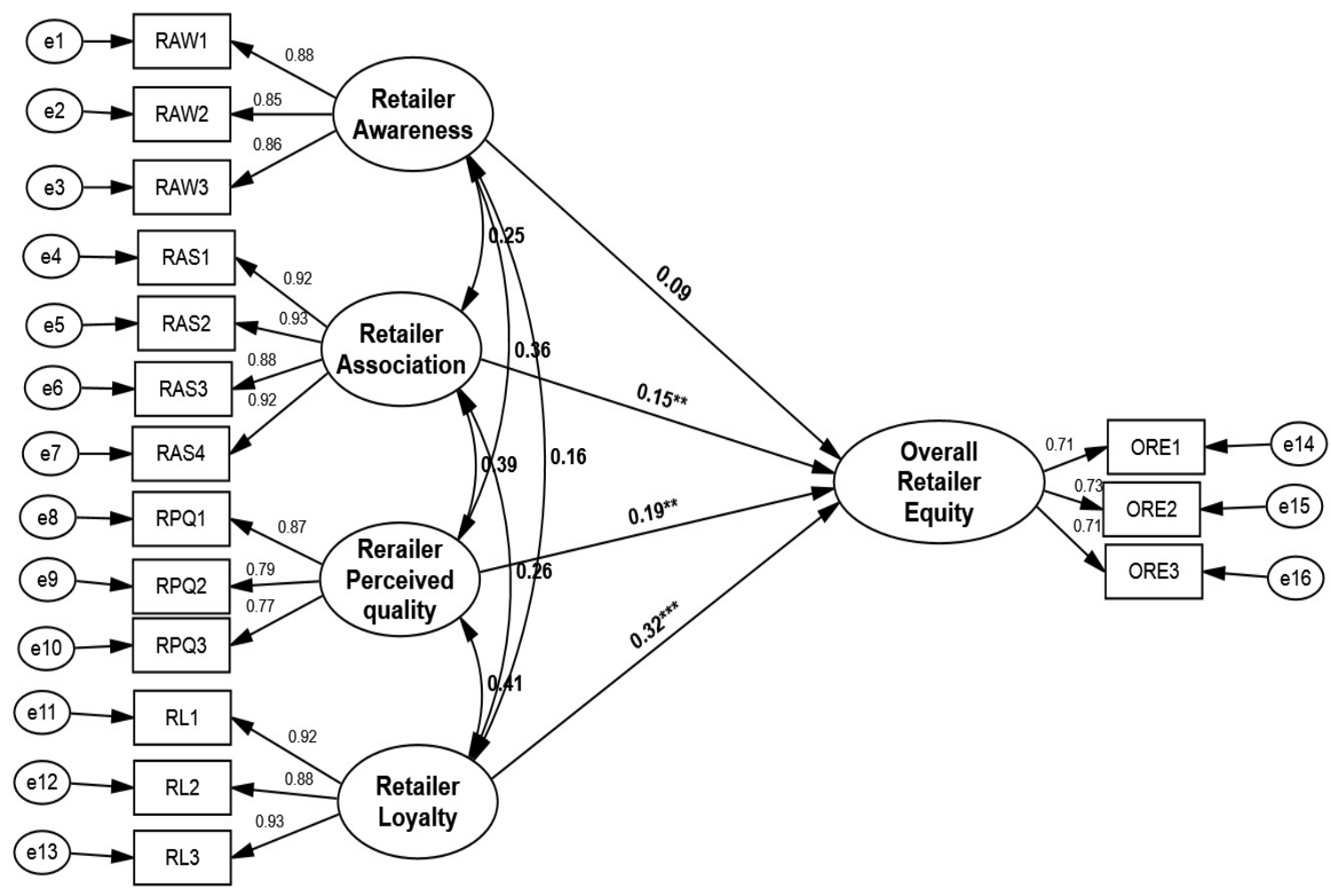

Figure 1. Results of Structural Equation Model

\subsection{Hypotheses testing}

The Results of structural model were able to support the statistically significant relationships between all the three exogenous constructs except brand awareness and overall retailer equity constructs (see table-3). It means except retailer awareness, all the three retailer equity constructs-retailer associations, retailer loyalty and perceived retailer quality have direct and significant effect on retailer overall equity. Among all the four dimensions, retailer loyalty has stronger and significant effect $(\beta=0.323, \mathrm{t}=4.815, \mathrm{p}=0.000<0.001)$ on retailer equity. On the other hand, retailer awareness has a weak and insignificant effect $(\beta=0.086, t=1.348$, $\mathrm{p}=.178>0.001$ ) on overall retailer equity (see the table 3 ). 
Table 3. Result of hypothesized paths analysis

\begin{tabular}{|c|c|c|c|c|c|c|}
\hline & Hypothesized Path & $\begin{array}{c}\text { Std. } \\
\text { Estimates }\end{array}$ & $\begin{array}{l}\text { Std. } \\
\text { Error }\end{array}$ & $t$-value & $\boldsymbol{P}$ & Result \\
\hline H1 & Retailer awareness $\rightarrow$ Overall retailer equity & 0.086 & 0.058 & 1.348 & .178 & NS \\
\hline $\mathrm{H} 2$ & Retailer association $\rightarrow$ Overall retailer equity & 0.150 & 0.058 & 2.355 & .019 & S \\
\hline $\mathrm{H} 3$ & Perceived retailer quality $\rightarrow$ Overall retailer equity & 0.193 & 0.086 & 2.534 & .011 & S \\
\hline \multirow[t]{2}{*}{$\mathrm{H} 4$} & Retailer loyalty $\rightarrow$ Overall retailer equity & 0.323 & 0.061 & 4.815 & $* * *$ & S \\
\hline & Note: $\mathrm{S}=$ Supported, $\mathrm{N}$ & Not supporte & $=\mathrm{P}<0.0$ & & & \\
\hline
\end{tabular}

\section{Discussions and managerial implications}

This study has adopted a verification approach to verify the applicability of brand equity frame work proposed by Aaker available in the existing literature by extending it to retail industry in India. The empirical data and statistical tests used for the present study has provided enough support for positive and significant impact of retailer associations, perceived retailer quality and retailer loyalty on overall retailer equity but not for retailer awareness. Thus, findings of this study was in line with the previous studies, such as Yoo et al. (2000), Kim and Kim (2004), Eda Atilgan and et al. (2005) and Xiao and Jana (2009) which were carried on in various industries. Hence, Aaker's brand equity frame work can be applicable to retail industry too.

Following implications can be derived from this study. Marketing managers should concentrate on tacking the retailer equity dimensions and in particularly retailer loyalty related activities on a continuous manner. By tracking the progress of brand equity and loyalty related activities over time, managers can be able to understand and estimate the effect of their efforts in long run. Similarly, it also has theoretical implication as the existing consumer based brand equity was verified with a fresh look in the context of India, which is one of the leading emerging economies in the world. Hence, findings of this study will be the great interest for the retailers, who wish to increase their brand equity with a view to increase market share, sale, and profits and so on. Thus, this study has both theoretical and practical implications in the field brand equity.

\section{Acknowledgment}

I would like to thank Dr. Spana Singh, Associate professor, School of Management studies, University of Hyderabad, India for her constant support in carrying out this study successfully and effectively. Also I extend my sincere gratitude to GCBSS committee, Kuala Lumpur for offering their kind support for this study.

\section{References}

Aaker, David A. (1991). Managing Brand Equity. New York: The Free Press.

Atilgan, E., Aksoy, S., \& Akinci, S. (2005). Determinants of the brand equity: a verification 
approach in the beverage industry in Turkey. Marketing intelligence \& planning, 23(3), 237-248.

Burmann, C., Jost-Benz, M., \& Riley, N. (2009). Towards an identity-based brand equity model. Journal of Business Research, 62(3), 390-397. http://dx.doi.org/10.1016/j.jbusres.2008.06.009

Doyle, J. P., Filo, K., McDonald, H., \& Funk, D. C. (2013). Exploring sport brand double jeopardy: The link between team market share and attitudinal loyalty. Sport Management Review, 16(3), 285-297. http://dx.doi.org/10.1016/j.smr.2012.11.001

Farquhar, P. H., Han, J. Y., \& Ijiri, Y. (1991). Recognizing and measuring brand assets. Report/Marketing Science Institute (USA).

Grewal, D., Krishnan, R., Baker, J., \& Borin, N. (1998). The effect of store name, brand name and price discounts on consumers' evaluations and purchase intentions. Journal of retailing, 74(3), 331-352. http://dx.doi.org/10.1016/S0022-4359(99)80099-2

Hair, J., Black, W., Babin, B., and Anderson, R. (2010). Multivariate data analysis (7th ed.): Prentice-Hall, Inc. Upper Saddle River, NJ, USA.

Jinfeng, W., \& Zhilong, T. (2009). The impact of selected store image dimensions on retailer equity: evidence from 10 Chinese hypermarkets. Journal of Retailing and Consumer Services, 16(6), 486-494. http://dx.doi.org/10.1016/j.jretconser.2009.08.002

Jung, J., \& Sung, E. (2008). Consumer-based brand equity: Comparisons among Americans and South Koreans in the USA and South Koreans in Korea. Journal of Fashion Marketing and Management, 12(1), 24-35. http://dx.doi.org/10.1108/13612020810857925

Keller, K. L. (1993). Conceptualizing, measuring, and managing customer-based brand equity. The Journal of Marketing, 1-22. http://dx.doi.org/10.2307/1252054

Kim, K. H., Kim, K. S., Kim, D. Y., Kim, J. H., \& Kang, S. H. (2008). Brand equity in hospital marketing. Journal of business research, 61(1), 75-82. http://dx.doi.org/10.1016/j.jbusres.2006.05.010

Kim, K. H., Ko, E., Xu, B., \& Han, Y. (2012). Increasing customer equity of luxury fashion brands through nurturing consumer attitude. Journal of Business Research, 65(10), 1495-1499. http://dx.doi.org/10.1016/j.jbusres.2011.10.016

Lassar, W., Mittal, B., \& Sharma, A. (1995). Measuring customer-based brand equity. Journal of consumer marketing, 12(4), 11-19. http://dx.doi.org/10.1108/07363769510095270

Macdonald, E. K., \& Sharp, B. M. (2000). Brand Awareness Effects on Consumer Decision Making for a Common, Repeat Purchase Product: A Replication. Journal of business research, 48(1), 5-15. http://dx.doi.org/10.1016/S0148-2963(98)00070-8

Netemeyer, R. G., Krishnan, B., Pullig, C., Wang, G., Yagci, M., Dean, D., Joe Ricks, \& Wirth, F. (2004). Developing and validating measures of facets of customer-based brand equity. Journal of Business Research, 57(2), 209-224. 
http://dx.doi.org/10.1016/S0148-2963(01)00303-4

Pappu, R., Quester, P. G., \& Cooksey, R. W. (2005). Consumer-based brand equity: improving the measurement-empirical evidence. Journal of Product \& Brand Management, 14(3), 143-154. http://dx.doi.org/10.1108/10610420510601012

Pappu, R., \& Quester, P. (2006). A consumer-based method for retailer equity measurement: results of an empirical study. Journal of Retailing and Consumer Services, 13(5), 317-329. http://dx.doi.org/10.1016/j.jretconser.2005.10.002

Percy, L., \& Rossiter, J. R. (1992). A model of brand awareness and brand attitude advertising $\begin{array}{llll}\text { strategies. } & \text { Psychology } \quad \& \quad \text { Marketing, 263-274. }\end{array}$ http://dx.doi.org/10.1002/mar.4220090402

Romaniuk, J., \& Nenycz-Thiel, M. (2013). Behavioral brand loyalty and consumer brand associations. Journal of Business Research, 66(1), 67-72. http://dx.doi.org/10.1016/j.jbusres.2011.07.024

Taskin, C., \& Akat, O. (2010). Measurement of Consumer Based Brand Equity Using Structural Equation Modeling and A Research in Durable Consumer Goods Sector. Business and Economics Research Journal, 1(2).

Tong, X., \& Hawley, J. M. (2009). Measuring customer-based brand equity: empirical evidence from the sportswear market in China. Journal of Product \& Brand Management, 18(4), 262-271. http://dx.doi.org/10.1108/10610420910972783

Uslu, A., Durmuş, B., \& Kolivar, B. K. (2013). Analyzing the brand equity of Turkish airlines services: Comparing the Japanese and Turkish perspectives. Procedia-Social and Behavioral Sciences, 99, 446-454. http://dx.doi.org/10.1016/j.sbspro.2013.10.513

Vazquez, R., Del Rio, A. B., \& Iglesias, V. (2002). Consumer-based brand equity: development and validation of a measurement instrument. Journal of Marketing management, 18(1-2), 27-48. http://dx.doi.org/10.1362/0267257022775882

Washburn, J. H., \& Plank, R. E. (2002). Measuring brand equity: an evaluation of a consumer based brand equity scale. Journal of Marketing Theory and Practice, 46-62.

Yoo, B., Donthu, N., \& Lee, S. (2000). An examination of selected marketing mix elements and brand equity. Journal of the Academy of Marketing Science, 28(2), 195-211. http://dx.doi.org/10.1177/0092070300282002

Yoo, B., \& Donthu, N. (2001).Developing and validating a multidimensional consumer-based brand equity scale. Journal of business research, 52(1), 1-14. http://dx.doi.org/10.1016/S0148-2963(99)00098-3

Zeithaml, V.A. (1988), "Consumer perceptions of price, quality, and value: a means-end model and synthesis of evidence", Journal of Marketing, 52(3), 2-22. http://dx.doi.org/10.2307/1251446 


\section{Macrothink}

\section{Copyright Disclaimer}

Copyright for this article is retained by the author(s), with first publication rights granted to the journal.

This is an open-access article distributed under the terms and conditions of the Creative Commons Attribution license (http://creativecommons.org/licenses/by/3.0/). 